Article

\title{
Field-Scale Characterization of Spatio-Temporal Variability of Soil Salinity in Three Dimensions
}

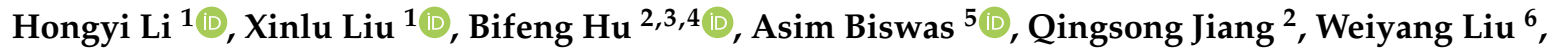 \\ Nan Wang ${ }^{2}$ and Jie Peng ${ }^{6, *}$ \\ 1 Department of Land Resource Management, School of Tourism and Urban Management, \\ Jiangxi University of Finance and Economics, Nanchang 330013, China; lihongyi1981@zju.edu.cn (H.L.); \\ 2201920471@stu.jxufe.edu.cn (X.L.) \\ 2 College of Environment and Resources, Zhejiang University, Hangzhou 310058, China; \\ hubifeng@zju.edu.cn (B.H.); 11614053@zju.edu.cn (Q.J.); wangnanfree@zju.edu.cn (N.W.) \\ 3 Unité de Recherche en Science du Sol, INRAE, 45075 Orléans, France \\ 4 Sciences de la Terre et de l'Univers, Orléans University, 45067 Orléans, France \\ 5 School of Environmental Sciences, University of Guelph, 50 Stone Road East, \\ Guelph, ON N1G 2W1, Canada; biswas@uoguelph.ca \\ 6 College of Plant Science, Tarim University, Alar 843300, China; lwyzky@taru.edu.cn \\ * Correspondence: $11414049 @ z j u . e d u . c n$
}

Received: 3 November 2020; Accepted: 7 December 2020; Published: 10 December 2020

check for updates

\begin{abstract}
Information on spatial, temporal, and depth variability of soil salinity at field and landscape scales is important for a variety of agronomic and environment concerns including irrigation in arid and semi-arid areas. However, challenges remain in characterizing and monitoring soil secondary salinity as it can largely be impacted by managements including irrigation and mulching in addition to natural factors. The objective of this study is to evaluate apparent electrical conductivity $\left(\mathrm{EC}_{\mathrm{a}}\right)$-directed soil sampling as a basis for monitoring management-induced spatio-temporal change in soil salinity in three dimensions. A field experiment was conducted on an 18-ha saline-sodic field from Alar's Agricultural Science and Technology Park, China between March, and November 2018. Soil EC $\mathrm{E}_{\mathrm{a}}$ was measured using an electromagnetic induction (EMI) sensor for four times over the growing season and soil core samples were collected from 18 locations (each time) selected using EMI survey data as a-priori information. A multi-variate regression-based predictive relationship between $\mathrm{EC}_{\mathrm{a}}$ and laboratory-measured electrical conductivity $\left(\mathrm{EC}_{\mathrm{e}}\right)$ was used to predict $\mathrm{EC}$ with confidence $\left(R^{2}\right.$ between 0.82 and 0.99 ). A three-dimensional inverse distance weighing (3D-IDW) interpolation clearly showed a strong variability in space and time and with depths within the study field which were mainly attributed to the human management factors including irrigation, mulching, and uncovering of soils and natural factors including air temperature, evaporation, and groundwater level. This study lays a foundation of characterizing secondary salinity at a field scale for precision and sustainable management of agricultural lands in arid and semi-arid areas.
\end{abstract}

Keywords: soil profile; soil salinization; spatio-temporal variation; electromagnetic induction; three-dimension visualization

\section{Introduction}

Soil salinization is one of the critical global problems threatening land productivity [1]. Saline soils have been reported from more than 100 countries around the world and covers more than 1125 million hectares of land [2]. It is increasing at about $1-2 \%$ every year and is estimated that $50 \%$ of the available arable lands can be affected by soil salinity by 2050 and would pose a serious threat to the sustainable development of global agriculture [3]. Salinity could form from both natural and artificial sources 
including human-induced land management. Low precipitation, high evapotranspiration, and saline groundwater often contribute largely in soil salinization in arid and semi-arid environments [4]. Secondary salinization or human-induced management-driven salinization of agricultural farmlands mainly in the arid and semi-arid desert environments cover more than 76 million ha area [2] and became one of the serious environmental and resource problems affecting the ecosystem. Unlike natural salinization and humid area, intense climate and short salt migration cycle with high frequency as impacted by management create a very high spatial and temporal variations in soil salinity and make the measurement, monitoring, and/or prediction highly difficult using traditional methods and analysis. The strong spatio-temporal variability with depth adds difficulty in predicting soil salinity in three dimensions using traditional methods of field sampling combined with laboratory analysis while the field scale information is crucial for agronomic and environmental management decisions. For example, information on salt content in addition to soil moisture in a profile is important for irrigation scheduling as this may cause physiological drought [5]. Thus, a simple, fast, and accurate methods to monitor soil salt content in three dimensions (space, time, and depth) is urgently needed to ensure the safe and efficient production of salinized and secondary salinized farmlands in particular arid and semi-arid regions [6,7].

Since the 1970s, apparent electrical conductivity measurement using electromagnetic induction (EMI) technology helped characterizing, monitoring, and evaluating soil salinity [8-13]. It can more efficiently and quickly obtain in situ salinity information at different depths by measuring apparent conductivity and helped overcome some challenges in traditional sampling methods and reduce costs [14]. For example, Guo et al. [15] mapped the spatio-temporal variation of soil salinity at different site-specific areas based on EM38, which provide valuable information for formulating suitable management strategies against soil salinization. Jiang et al. [16] used EMI technology and three-dimensional (3D) inversion models to quantify spatial variability of soil salinity under four typical land-use types in Aksu, Xinjiang.

Quantifying spatio-temporal variations of soil salinity in 3D can help understand dynamic changes and help determine the degree of salinization and develop management strategies. Geostatistics is one of the most effective methods to study spatial variability of soil properties [17-22]. Three-dimensional geostatistics and Kriging have shown strong potential to capture and quantify spatial variability in 3D in different fields including precision agriculture [23]. It has also been used in quantifying soil salinity. For example, Li et al. [24] used three-dimensional ordinary Kriging interpolation to predict the spatial variation of soil salt in paddy fields. Liu et al. [25] used the three-dimensional ordinary Kriging interpolation method to evaluate the spatial variation of soil salinity in the Yellow River Delta in China. While these studies showed the potential of quantifying soil salinity in 3D from EMI sensor data and Kriging interpolation, quantification of soil salinity at a point of time could not capture the dynamics of soil salinization. For example, in arid and semi-arid areas, because of the high evaporation over precipitation, salts frequently migrate, redistribute, and accumulate in the soil profile with changes in precipitation, irrigation water, and evaporation. Salt dynamics as impacted by management can greatly affect crop growth. Thus, it is critical to characterize and quantify spatio-temporal variations of soil salinity at different depths to develop effective strategies such as irrigation to manage secondary soil salinity in arid regions. It can also provide important information for regional salinized land restoration, and scientific improvement and prevention of land degradation. The overall objective of this study is to characterize and quantify dynamics of spatio-temporal variability of soil salinity in three dimensions. This study used in situ apparent electrical conductivity measured using EMI sensors and 3D inverse distance weighing interpolation to quantify spatio-temporal dynamics of soil salinity at multiple depths under cotton irrigated with different amounts of irrigation from the arid area of Xinjiang Uygur Autonomous Region in Northwest of China. 


\section{Materials and Methods}

\subsection{Study Area}

Xinjiang is the most important production base for high-quality cotton and fruits in China. In 2017, the cotton planting area in Xinjiang accounted for $80 \%$ of China with a plant area of around 2,217,000 ha. A field experiment was conducted at the National Agricultural Science and Technology Park of Alar City, southern Xinjiang $\left(80^{\circ} 30^{\prime} \sim 81^{\circ} 58^{\prime} \mathrm{E}\right.$ and $\left.40^{\circ} 22^{\prime} \sim 40^{\circ} 57^{\prime} \mathrm{N}\right)$ (Figure 1). It is in the flood plain and delta zone of the upper Tarim River and at the confluence of Hetian River, Aksu River, and Yeerqiang River. The terrain is high in the southwest and low in the northeast with mild slope of about 0.3 to $0.7 \%$. The average annual evaporation is $1988 \mathrm{~mm}$, and the average annual precipitation is $48.5 \mathrm{~mm}$. The main crop in the park is cotton, and the agricultural production level is high, which is reflected in the high level of crop yield per unit area, high degree of agricultural mechanization, and high degree of intensification. The large-scale, standardized, and industrialized production and management in the park provide a demonstration role for the agricultural production in southern Xinjiang. The experimental field is about $18 \mathrm{hm}^{2}$ in area and was planted with Xinluzhong No. 78 variety of cotton. During spring and winter, flood irrigation was employed to leach salts, while drip irrigation was adopted for the cropping period. The winter irrigation was carried out on November 20, with a total amount of $59,400 \mathrm{~m}^{3}$. A total of five irrigations were applied over the growing period; first irrigation was on 22 June with $450 \mathrm{~m}^{3} \mathrm{hm}^{-2}$ of water, and the second, third, fourth, and fifth irrigations were applied on 9 July, 25 July, 13 August, and 25 August, respectively with $600 \mathrm{~m}^{3} \mathrm{hm}^{-2}$ of water each time. The soil type is Calcaric Cambisols on study area. The soil texture of the study area is sandy loam, and the soil organic matter content is between 6.3 and $13.93 \mathrm{~g} \mathrm{~kg}^{-1}$, with an average content of $8.76 \mathrm{~g} \mathrm{~kg}^{-1}$.

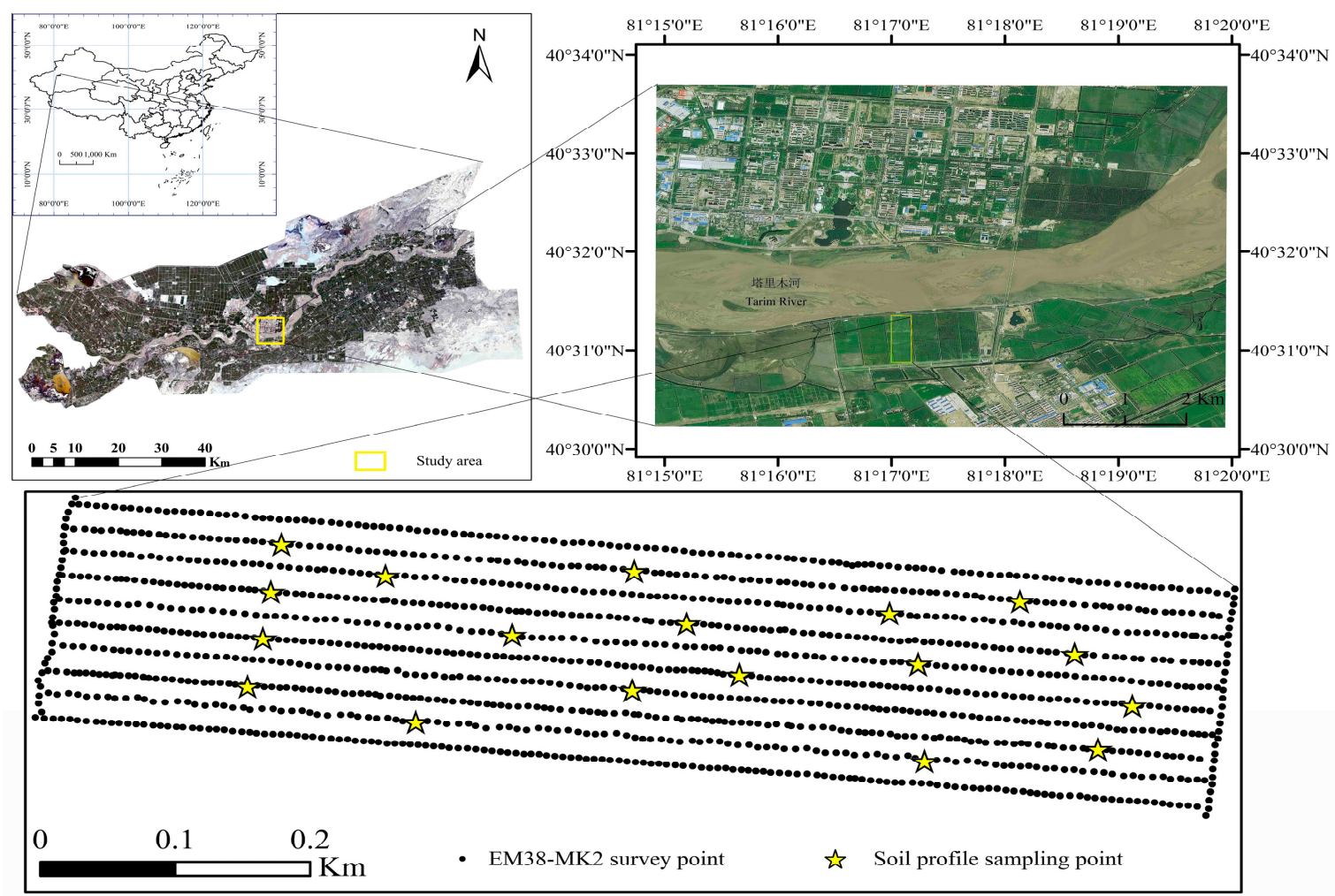

Figure 1. Geographical location of experimental area and distribution of EM38-MK2 survey sites. 


\subsection{Field Measurement of Soil Apparent Electrical Conductivity}

An EMI sensor (geodetic conductivity meter, EM38-MK2) (Geonics Ltd., Mississauga, ON, Canada) was used in this study to in situ measure soil apparent electrical conductivity $\left(\mathrm{EC}_{\mathrm{a}}, \mathrm{mS} / \mathrm{m}\right)$. While the original EM38 model carries a transmitter and a receiver coil at 1-m apart, the EM38-MK2 model carries two receiver coils at $0.5 \mathrm{~m}$ and $1.0 \mathrm{~m}$ far from the transmitter coil and can provide $\mathrm{EC}_{\mathrm{a}}$ data at four different depths [26]. The new EM38-MK2 model also adopts new technology to automatically perform temperature compensation, correct circuit faults, and eliminate data drift caused by the temperature variations [27].

An EM38-MK2 model was embedded into a wooden cart along with a GPS and was used to map the whole field for four times between July and October. Measurements were done on 15 March 2018 (after winter irrigation) before cotton sowing, 3 June (before the first drip irrigation), 7 July (before the second drip irrigation), and 27 October (after cotton harvesting but before winter irrigation) using the vertical measurement mode from south to north of the survey field. More details of the experiment and data collection can be found in Liu et al. [28]. Based on the spatial scale of the study area, a total of ten measurement rows were developed with a row spacing of $20 \mathrm{~m}$ (Figure 1). Descriptive details of the soil $\mathrm{EC}_{\mathrm{a}}$ measurement are presented in Table 1.

Table 1. The statistical characteristic values of geospatial electromagnetic induction measurements of apparent electrical conductivity $\left(\mathrm{EC}_{\mathrm{a}}\right)$ at different periods.

\begin{tabular}{|c|c|c|c|c|c|c|c|}
\hline Date & $\mathrm{EC}_{\mathbf{a}}$ & $\operatorname{Min}\left(\mathrm{dS} \mathrm{m}^{-1}\right)$ & $\operatorname{Max}\left(\mathrm{dSm}^{-1}\right)$ & Mean $\left(\mathrm{dSm}^{-1}\right)$ & CV (\%) & Skew & Kurt. \\
\hline \multirow[t]{2}{*}{15 March 2018} & $\mathrm{EC}_{\mathrm{V} 1.5}$ & 0.26 & 2.05 & 0.77 & 0.63 & 1.51 & 1.34 \\
\hline & $\mathrm{EC}_{\mathrm{V} 0.75}$ & 0.05 & 2.61 & 0.63 & 0.96 & 6.21 & 2.19 \\
\hline \multirow[t]{2}{*}{3 June 2018} & $\mathrm{EC}_{\mathrm{V} 1.5}$ & 0.20 & 1.39 & 0.72 & 0.51 & -1.16 & 0.29 \\
\hline & $\mathrm{EC}_{\mathrm{V} 0.75}$ & 0.13 & 1.73 & 0.62 & 0.75 & 0.18 & 1.04 \\
\hline \multirow[t]{2}{*}{7 July 2020} & $\mathrm{EC}_{\mathrm{V} 1.5}$ & 0.19 & 1.60 & 0.79 & 0.52 & -0.64 & 0.22 \\
\hline & $\mathrm{EC}_{\mathrm{V} 0.75}$ & 0.36 & 2.21 & 1.16 & 0.56 & -1.57 & 0.35 \\
\hline \multirow[t]{2}{*}{27 October 2018} & $\mathrm{EC}_{\mathrm{V} 1.5}$ & 0.44 & 1.99 & 1.00 & 0.46 & -0.29 & 0.90 \\
\hline & $\mathrm{EC}_{\mathrm{V} 0.75}$ & 0.49 & 1.78 & 1.05 & 0.41 & -1.10 & 0.46 \\
\hline
\end{tabular}

\subsection{Soil Sampling and Analysis}

To model the relationship between the measured electrical conductivity and the apparent electrical conductivity, soil profile samples were collected from the field. While high density sampling can ensure the stability of the relationship, it largely increases cost, time, and labor. In contrast, EM38-MK2 survey provides relative variability of soil salinization within the field and can be used to select sampling locations a priori while capturing the variability. Roughly, the EM38-MK2 soil apparent electrical conductivity data were divided into three groups: low ( $\left.<50 \mathrm{mS} \mathrm{m}^{-1}\right)$, medium (50 100 mS $\left.\mathrm{m}^{-1}\right)$, and high $\left(>100 \mathrm{mS} \mathrm{m}^{-1}\right)$. Six sampling locations were randomly selected within each of these zones identified from the EM38-MK2 survey data. A total of 18 soil cores were collected each time for four times (15 March, 3 June, 7 July, and 27 October 2018) of field measurement. The profiles were then sub-sampled at 0-20, 20-40, 40-60, 60-80, and 80-100 cm depth layers, placed in plastic bags, numbered, and sent to laboratory for further analysis [28,29]. The soil samples were immediately tested for soil moisture content using the over drying method. Remaining soil samples were air-dried, gravel, roots, and other visible residues were picked out, and ground and passed through a 2-mm sieve. After preparing the soil saturated extract [28,30], the LeiCi DDS-307A (Shengke, Shanghai, China) conductivity meter was used to determine the soil conductivity ECe $\left(\mathrm{dS} \mathrm{m}^{-1}\right)$.

\subsection{Model Construction and Evaluation}

The 18 soil profiles were sorted and randomly divided into training dataset (12 profiles) and validated dataset (6 profiles) at a ratio of 2:1. Linear and multivariate linear regression methods were used to construct a predictive relationship between measured soil electrical conductivity and 
soil apparent electrical conductivity. Coefficient of determination $\left(R^{2}\right)$, root mean squared error (RMSE), relative percent deviation (RPD), and mean error (ME) were calculated to evaluate the model performance. The related formulas are as follows:

Mean error:

$$
\mathrm{ME}=\frac{1}{m} \sum_{i=1}^{N}\left[z^{*}\left(s_{i}\right)-z\left(s_{i}\right)\right]
$$

Root-mean-square error:

$$
\text { RMSE }=\sqrt{\frac{1}{N} \sum_{i=1}^{N}\left[z^{*}\left(s_{i}\right)-z\left(s_{i}\right)\right]^{2}}
$$

Coefficient of determination:

$$
R^{2}=\left[\frac{\sum_{i=1}^{N}\left(z\left(s_{i}\right)-z\left(s_{i}\right)_{\text {ave }}\right)\left(z^{*}\left(s_{i}\right)-z^{*}\left(s_{i}\right)_{\text {ave }}\right)}{\sqrt{\sum_{i=1}^{N}\left(z\left(s_{i}\right)-z\left(s_{i}\right)_{\text {ave }}\right)^{2}+\sum_{i=1}^{N}\left(z^{*}\left(s_{i}\right)-z^{*}\left(s_{i}\right) \text { ave }\right)^{2}}}\right]^{2}
$$

Standard deviation:

$$
\mathrm{SD}=\sqrt{\frac{\sum_{i=1}^{N}\left(z\left(s_{i}\right)-z\left(s_{i}\right)_{a v e}\right)^{2}}{n-1}}
$$

Relative percent deviation:

$$
\mathrm{RPD}=\frac{S D}{R M S E}
$$

where $z^{*}\left(s_{i}\right)$ was the predicted value, and $z\left(s_{i}\right)$ was the measured value. $z^{*}\left(s_{i}\right)_{\text {ave }}$ and $z\left(s_{i}\right)_{\text {ave }}$ were the averaged predicted and measured value, respectively. $N$ was the sample number. A RPD $\geq 2.0$ indicates a good predictive ability of the model and a $R^{2}$ value close to 1 , RMSE close to 0 , ME close to 0 indicate better model performance $[23,31,32]$.

\subsection{Spatial Interpolation and Mapping}

Three-dimensional inverse distance weighting (3D-IDW) is one of the most used techniques for three-dimensional interpolation. IDW is based on the basic assumption of the "first law of geography": that is, the similarity of two objects decreases as the distance between them increases. The weights were calculated based on the distance between the observed points. The closer the sample point is, the greater is the weight. This study used the method of calculating weight coefficients of known points improved by Frank and Nielson in 1980 [33], which can obtain higher precision results than Shepard's classic method [12]. The relevant calculation formulas are:

$$
\begin{gathered}
F(x, y, z)=\sum_{i=1}^{n} w_{i} f_{i} \\
w_{i}=\left[\frac{R-h_{i}}{R h_{i}}\right]^{2} / \sum_{i=1}^{n}\left[\frac{R-h_{i}}{R h_{i}}\right]^{2} \\
h_{i}=\sqrt{\left(x-x_{i}\right)^{2}+\left(y-y_{i}\right)^{2}+\left(z-z_{i}\right)^{2}}
\end{gathered}
$$

where, $F$ is the attribute value of the point to be estimated; $w_{i}$ is the weight coefficient assigned to the point to be estimated; $h_{i}$ is the distance from the point to be estimated to the interpolation point; $R$ is the distance from the interpolation point to the farthest point to be estimated; $n$ is the total number of points to be estimated; $(x, y, z)$ are the coordinates of each interpolation point; $\left(x_{i}, y_{i}, z_{i}\right)$ are the coordinates of each point to be estimated; and $f_{i}$ is the attribute value of the known interpolation point. In interpolating, $75 \%$ (7500) of the total number of samples from different periods $(10,000)$ were used 
as the training data set, and $25 \%$ as the independent validation data set. The RMSE, ME, $R^{2}$ between the measured value and the measured value were calculated to assess the model performance [12,34].

\section{Results}

\subsection{Predictive Relationship between ECe and ECa}

Best of linear and multiple linear regression relationships between ECe and ECa at five different depths and four different times are presented in Table 2. The relationships were developed for ECe values of 12 profiles (calibration dataset) and validated with the rest six profiles (validation dataset) against two depths of EM38-MK2 measurement; $\mathrm{EC}_{\mathrm{v} 0.75}$ and $\mathrm{EC}_{\mathrm{v} 1.5}$ measuring $\mathrm{ECa}$ to the depth of $0.75 \mathrm{~m}$ and $1.5 \mathrm{~m}$. In general, multiple linear regression always outperformed linear regression results with $R^{2}$ ranging from 0.70 to 0.96 .

Table 2. Predictive relationship of soil conductivity at different depths and periods.

\begin{tabular}{|c|c|c|c|c|c|c|c|c|}
\hline \multirow{2}{*}{$\begin{array}{c}\text { Soil } \\
\text { Layer/cm }\end{array}$} & \multicolumn{2}{|l|}{15 March 2018} & \multicolumn{2}{|l|}{3 June 2018} & \multicolumn{2}{|l|}{7 July 2018} & \multicolumn{2}{|c|}{27 October 2018} \\
\hline & Models & $R^{2}$ & Models & $R^{2}$ & Models & $R^{2}$ & Models & $R^{2}$ \\
\hline $0 \sim 20$ & $\begin{array}{c}\mathrm{ECe}=0.178 \mathrm{X}_{1}- \\
0.003 \mathrm{X}_{2}+0.275\end{array}$ & 0.91 & $\begin{array}{c}\mathrm{ECe}=0.101 \mathrm{X}_{1}- \\
0.085 \mathrm{X}_{2}+3.368\end{array}$ & 0.94 & $\begin{array}{l}\mathrm{ECe}=0.045 \mathrm{X}_{1}- \\
0.028 \mathrm{X}_{2}+0.981\end{array}$ & 0.75 & $\begin{array}{c}\mathrm{ECe}=-0.001 X_{1}+ \\
0.055 X_{2}-0.170\end{array}$ & 0.93 \\
\hline $20 \sim 40$ & $\begin{array}{c}\mathrm{ECe}=-0.007 \mathrm{X}_{1}+ \\
0.026 \mathrm{X}_{2}-0.556\end{array}$ & 0.80 & $\begin{array}{c}\mathrm{ECe}=0.025 \mathrm{X}_{1}- \\
0.011 \mathrm{X}_{2}+0.296\end{array}$ & 0.77 & $\begin{array}{c}\mathrm{ECe}=0.007 \mathrm{X}_{1}+ \\
0.017 \mathrm{X}_{2}-0.516\end{array}$ & 0.81 & $\begin{array}{l}\mathrm{ECe}=0.020 \mathrm{X}_{1}- \\
0.004 \mathrm{X}_{2}+0.886\end{array}$ & 0.96 \\
\hline $40 \sim 60$ & $\begin{array}{c}\mathrm{ECe}=0.003 \mathrm{X}_{1}+ \\
0.012 \mathrm{X}_{2}-0.194\end{array}$ & 0.90 & $\begin{array}{c}\mathrm{ECe}=0.003 \mathrm{X}_{1}+ \\
0.018 \mathrm{X}_{2}-0.318\end{array}$ & 0.79 & $\begin{array}{l}\mathrm{ECe}=0.002 \mathrm{X}_{1}+ \\
0.011 \mathrm{X}_{2}-0.075\end{array}$ & 0.76 & $\begin{array}{c}\mathrm{ECe}=0.0004 \mathrm{X}_{1}+ \\
0.012 \mathrm{X}_{2}+0.607\end{array}$ & 0.96 \\
\hline $60 \sim 80$ & $\begin{array}{c}\mathrm{ECe}=0.004 \mathrm{X}_{1}+ \\
0.011 \mathrm{X}_{2}-0.135\end{array}$ & 0.91 & $\begin{array}{c}\mathrm{ECe}=0.001 \mathrm{X}_{1}+ \\
0.017 \mathrm{X}_{2}-0.188\end{array}$ & 0.82 & $\begin{array}{l}\mathrm{ECe}=0.003 \mathrm{X}_{1}+ \\
0.022 \mathrm{X}_{2}-0.895\end{array}$ & 0.82 & $\begin{array}{l}\mathrm{ECe}=0.013 \mathrm{X}_{1}- \\
0.002 \mathrm{X}_{2}+0.327\end{array}$ & 0.90 \\
\hline $80 \sim 100$ & $\begin{array}{c}\mathrm{ECe}=-0.001 \mathrm{X}_{1}+ \\
0.013 \mathrm{X}_{2}-0.064\end{array}$ & 0.86 & $\begin{array}{c}\mathrm{ECe}=-0.00 \mathrm{X}_{1}+ \\
0.021 \mathrm{X}_{2}-0.045\end{array}$ & 0.78 & $\begin{array}{c}\mathrm{ECe}=-0.001 \mathrm{X}_{1}+ \\
0.012 \mathrm{X}_{2}-0.002\end{array}$ & 0.70 & $\begin{array}{c}\mathrm{ECe}=0.008 \mathrm{X}_{1}- \\
0.001 \mathrm{X}_{2}+0.352\end{array}$ & 0.93 \\
\hline
\end{tabular}

The performance of the validation of these relationships are presented in Table 3. Overall, the relationships showed strong agreement with $R^{2}>0.80$, ME ranged between -0.45 and 0.32 , RMSE $<1.30 \mathrm{dS} \mathrm{m}^{-1}$ and RPD $>2.0$ for all models. These clearly showed that the predictive models have good ability and the ECa of EM38-MK2 can be successfully used to accurately estimate soil ECe both in space and with depths. The predictive models of each soil layer in different periods were then applied to the entire field, and the conductivity of each soil layer in different periods was obtained which were then used to interpolate using 3D-IDW to quantify spatio-temporal variation of soil salinization.

\subsection{Temporal Variation of Soil Salinity}

Descriptive statistics of predicted ECs from EM38-MK2 measured ECa data at different soil layers and depths are presented in Table 4. Great differences were observed among the temporal distribution characteristics and salt content in the soil profile. The salt content in March showed minor variations in the distribution within the profiles with an average value between 0.78 and $0.88 \mathrm{dS} \mathrm{m}^{-1}$, a relatively low amount. This is mainly attributed to the flood irrigation used during winter to wash the salts of the $0-100 \mathrm{~cm}$ soil profile. Following the desalinization, the soil froze as the temperature went below $0{ }^{\circ} \mathrm{C}$ during winter and the salts could not move within the profile. In contrast, soil profiles in June, July, and October showed obvious salt accumulation at surface layers. Salts in June and October were mainly concentrated in the surface $0-20 \mathrm{~cm}$ layer. The average conductivity of the topsoil $(0-20 \mathrm{~cm})$ layer in June and October was 3.32 and $5.28 \mathrm{dS} \mathrm{m}^{-1}$, respectively. Average soil conductivity of the other four soil layers $(20-100 \mathrm{~cm})$ in June and October ranged from 0.99 to $1.36 \mathrm{dS} \mathrm{m}^{-1}$, and 0.95 to $1.70 \mathrm{dS} \mathrm{m}^{-1}$, respectively. Accumulation of salts at $0-20 \mathrm{~cm}$ layer during this period is related to the lack of irrigation for a longer time. There was no irrigation between November 2017 (applied as winter irrigation) and 3 June 2018 (the first irrigation). Moreover, precipitation is also low during this period. In addition, during April, as the temperature in this area reached above $20^{\circ} \mathrm{C}$, evaporation became stronger. As the 
water left soil surface as evaporation, salts accumulated on the surface. However, salts were mainly concentrated within $0-40 \mathrm{~cm}$ layers during the July measurement. The average conductivity of $0-20 \mathrm{~cm}$ and $20-40 \mathrm{~cm}$ soil layer were 2.45 and $2.25 \mathrm{dS} \mathrm{m}^{-1}$, respectively. The amount of drip irrigation water contributed to the accumulation of salts in July at a depth of $0-40 \mathrm{~cm}$. The maximum drip irrigation water volume was only $600 \mathrm{~m}^{3} \mathrm{hm}^{-2}$, and the maximum wetting depth of this water volume was $40 \mathrm{~cm}$. Therefore, the salt accumulated in $0-20 \mathrm{~cm}$ in the early stage can only be transported within the soil depth of $0-40 \mathrm{~cm}$. The conductivity in deeper soil layers $\left(40-100 \mathrm{~cm}\right.$ ) ranged from 0.87 to $0.93 \mathrm{dS} \mathrm{m}^{-1}$.

Table 3. Cross-validated results of models for soil conductivity at different periods.

\begin{tabular}{cccccc}
\hline Date & Soil Layer/cm & $\boldsymbol{R}^{\mathbf{2}}$ & ME & RMSE & RPD \\
\hline \multirow{4}{*}{ 15 March 2018 } & $0 \sim 20$ & 0.82 & -0.24 & 0.51 & 2.01 \\
& $20 \sim 40$ & 0.85 & 0.02 & 0.41 & 2.51 \\
& $40 \sim 60$ & 0.93 & -0.06 & 0.26 & 3.03 \\
& $60 \sim 80$ & 0.87 & -0.25 & 0.48 & 2.02 \\
& $80 \sim 100$ & 0.85 & -0.16 & 0.46 & 2.02 \\
& $0 \sim 20$ & 0.85 & -0.09 & 0.86 & 2.47 \\
3 June 2018 & $20 \sim 40$ & 0.91 & -0.15 & 0.33 & 2.48 \\
& $40 \sim 60$ & 0.96 & 0.32 & 0.36 & 2.13 \\
& $60 \sim 80$ & 0.89 & -0.04 & 0.23 & 2.86 \\
& $80 \sim 100$ & 0.82 & 0.04 & 0.22 & 2.25 \\
7 July 2020 & $0 \sim 20$ & 0.89 & -0.12 & 1.22 & 2.23 \\
& $20 \sim 40$ & 0.91 & -0.02 & 0.50 & 2.50 \\
& $40 \sim 60$ & 0.98 & -0.15 & 0.35 & 2.01 \\
& $60 \sim 80$ & 0.98 & 0.20 & 0.40 & 2.09 \\
& $80 \sim 100$ & 0.96 & -0.01 & 0.10 & 4.78 \\
& $0 \sim 20$ & 0.99 & -0.45 & 0.56 & 4.56 \\
& $20 \sim 40$ & 0.92 & 0.05 & 0.21 & 3.35 \\
& $40 \sim 60$ & 0.95 & 0.04 & 0.17 & 3.73 \\
& $60 \sim 80$ & 0.94 & -0.02 & 0.13 & 3.97 \\
& $80 \sim 100$ & 0.98 & -0.02 & 0.04 & 6.77 \\
\hline
\end{tabular}

Table 4. The statistical characteristic values of soil salinity (ECe) attributes at different periods.

\begin{tabular}{|c|c|c|c|c|c|c|c|c|}
\hline Date & $\begin{array}{l}\text { Layer } \\
(\mathrm{cm})\end{array}$ & $\begin{array}{c}\text { Min } \\
\left(\mathrm{dS} \mathrm{m}^{-1}\right)\end{array}$ & $\begin{array}{c}\text { Max } \\
\left(\mathrm{d} S \mathrm{~m}^{-1}\right)\end{array}$ & $\begin{array}{c}\text { Mean } \\
\left(\mathrm{dS} \mathrm{m}^{-1}\right)\end{array}$ & SD & $\mathrm{CV}$ & Skew & Kurt. \\
\hline \multirow{5}{*}{15 March 2018} & $0 \sim 20$ & 0.35 & 3.19 & 0.88 & 0.48 & 0.55 & 1.63 & 2.48 \\
\hline & $20 \sim 40$ & 0.06 & 3.72 & 0.87 & 0.61 & 0.70 & 0.86 & 1.14 \\
\hline & $40 \sim 60$ & 0.13 & 2.76 & 0.78 & 0.45 & 0.58 & 1.08 & 1.01 \\
\hline & $60 \sim 80$ & 0.21 & 2.82 & 0.88 & 0.44 & 0.50 & 1.01 & 0.94 \\
\hline & $80 \sim 100$ & 0.23 & 2.39 & 0.81 & 0.35 & 0.43 & 0.93 & 0.92 \\
\hline \multirow{5}{*}{3 June 2018} & $0 \sim 20$ & 0.85 & 20.40 & 3.32 & 5.33 & 1.61 & -0.01 & -0.19 \\
\hline & $20 \sim 40$ & 0.01 & 5.99 & 1.28 & 1.38 & 1.08 & 0.21 & -0.34 \\
\hline & $40 \sim 60$ & 0.05 & 4.51 & 1.36 & 0.69 & 0.51 & 0.40 & 0.06 \\
\hline & $60 \sim 80$ & 0.06 & 4.11 & 1.09 & 0.64 & 0.59 & 0.45 & 0.17 \\
\hline & $80 \sim 100$ & 0.12 & 3.51 & 0.99 & 0.52 & 0.53 & 0.51 & 0.29 \\
\hline \multirow{5}{*}{7 July 2018} & $0 \sim 20$ & 0.26 & 6.89 & 2.45 & 1.22 & 0.50 & 0.97 & 0.03 \\
\hline & $20 \sim 40$ & 0.58 & 8.55 & 2.25 & 1.54 & 0.67 & 0.46 & -0.04 \\
\hline & $40 \sim 60$ & 0.04 & 2.92 & 0.87 & 0.50 & 0.57 & 0.46 & -0.03 \\
\hline & $60 \sim 80$ & 0.16 & 3.52 & 0.93 & 0.59 & 0.63 & 0.45 & 0.10 \\
\hline & $80 \sim 100$ & 0.05 & 3.63 & 0.88 & 0.48 & 0.55 & 0.47 & 0.96 \\
\hline \multirow{5}{*}{27 October 2018} & $0 \sim 20$ & 1.40 & 18.69 & 5.28 & 1.76 & 0.33 & 0.89 & 3.63 \\
\hline & $20 \sim 40$ & 0.15 & 5.17 & 1.41 & 0.80 & 0.57 & 0.20 & -0.44 \\
\hline & $40 \sim 60$ & 0.78 & 4.83 & 1.70 & 0.425 & 0.25 & 0.78 & 2.99 \\
\hline & $60 \sim 80$ & 0.09 & 3.30 & 0.95 & 0.45 & 0.47 & 0.26 & -0.11 \\
\hline & $80 \sim 100$ & 0.74 & 2.77 & 1.19 & 0.20 & 0.17 & 1.11 & 5.04 \\
\hline
\end{tabular}


From a general evaluation based on coefficient of variation, $\mathrm{CV}<0.1$ indicates weak variability, $0.1 \leq \mathrm{CV}<1.0$ indicates moderate variability, and $\mathrm{CV} \geq 1.0$ indicates strong variability [34]. The soil conductivity in different periods showed moderate variability except on 3 June which showed strong variability within $0-40 \mathrm{~cm}$ soil layer. It may be that the temperature reached at the highest in June and thus the evaporation compared with the other months [33]. This led to strong variability of surface soil water and salt. During this time, an extreme high salt content of $20.40 \mathrm{dS} \mathrm{m}-1$ was observed in the surface soil layer. Though, the skewness of soil conductivity was close to 0 , the kurtosis deviated from 3 indicating a deviation from normal distribution in soil salinity values. After logarithmic transformation, the distribution of soil conductivity approximated to the normal distribution, though there existed a long tail on the left because of the existence of outliers.

\subsection{Spatio-Temporal of Distribution of Soil Electrical Conductivity in Three Dimensions}

The predicted soil ECe from the ECa measurements and the models (Table 2) were used to characterize the spatio-temporal distribution of soil salinity in 3D. In visualizing the spatio-temporal distribution, a 3D gridded system was used in the format of $X-Y-Z$ for 3D-IDW interpolation where the $X$-axis was equal to the width of the field, i.e., $200 \mathrm{~m}$, the Y-axis was equal to the length of the field, i.e., $1000 \mathrm{~m}$, the Z-axis was the depth of the soil profile, i.e., $1 \mathrm{~m}$. The 3D grid system provided a voxel size of $10 \mathrm{~m} \times 10 \mathrm{~m} \times 0.01 \mathrm{~m}$ to a total of $20 \times 100 \times 10=20,000$ voxels or cells (Figure 2 ). In performing 3D-IDW interpolation, the $Z$ axis was enlarged by 300 times, and the number of search points was set to 6 [35], and then the map of spatio-temporal distribution of soil conductivity was obtained (Figure 3). Figure 3 intuitively revealed spatio-temporal variation of soil salinity in 3D and the simple visual observation could provide valuable information on the status of soil salinity [36] and development of management practices such as irrigation in cotton field.

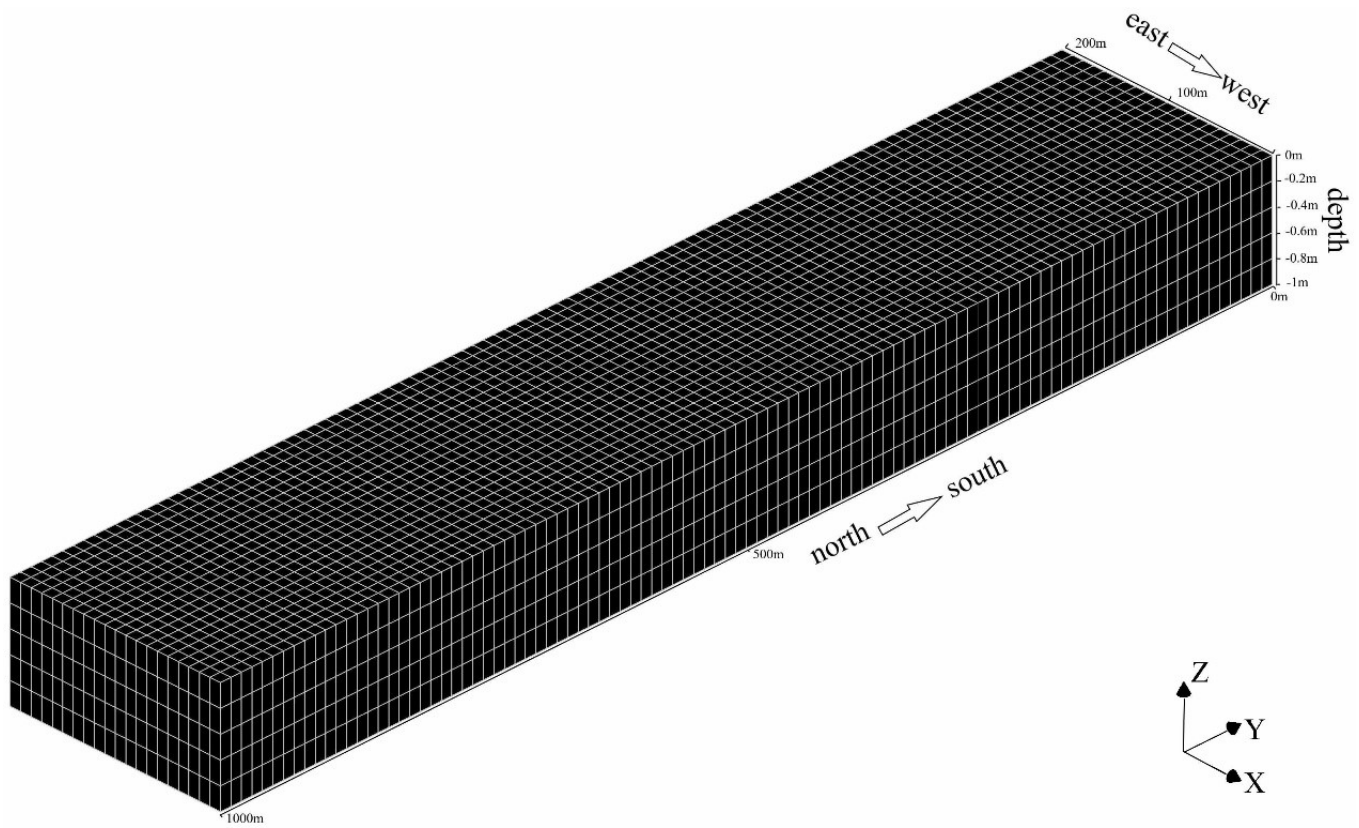

Figure 2. 3D mesh model of the test area. 

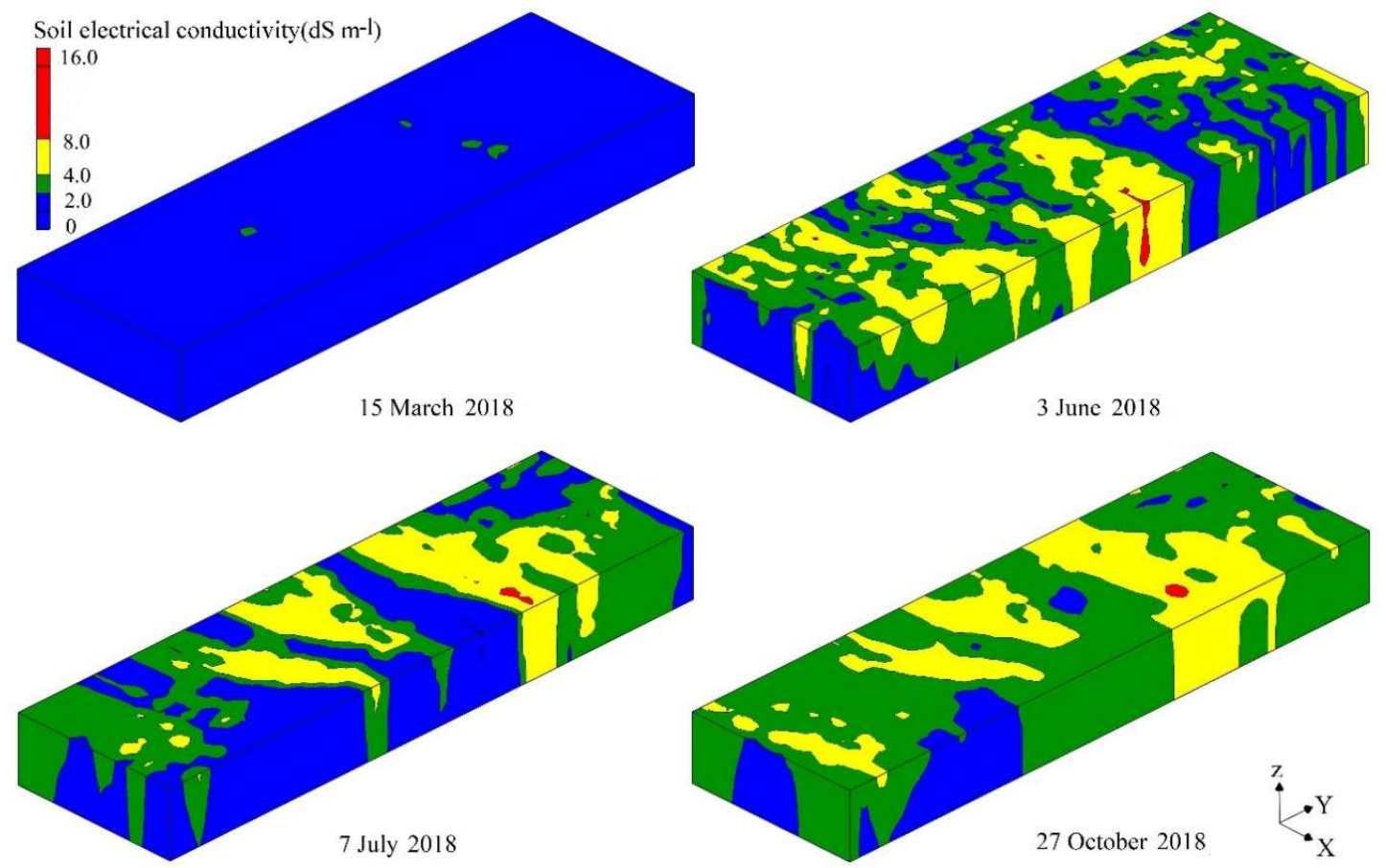

Figure 3. Three-dimensional distribution of soil salinity in different periods.

Following the grading standard of soil salinization defined by the American Salinity Laboratory [30], the soil ECe in this study was divided into five levels: non-saline soil $\left(0 \sim 2 \mathrm{dS} \mathrm{m}^{-1}\right)$, mildly saline soil $\left(2 \sim 4 \mathrm{dS} \mathrm{m}^{-1}\right)$, moderately saline soil $\left(4 \sim 8 \mathrm{dS} \mathrm{m}^{-1}\right)$, heavily saline soil $\left(8 \sim 16 \mathrm{dS} \mathrm{m}^{-1}\right)$, saline soil $\left(>16 \mathrm{dS} \mathrm{m}^{-1}\right)$. Most areas in March after winter irrigation exhibited low soil salinity (Figure 2), with an average soil conductivity of $0.84 \mathrm{dS} \mathrm{m}^{-1}$ and was categorized as non-saline soil. Between June and October with cotton on ground, soils were categorized as mildly saline soil, moderately saline soil, and heavily saline soil. While heavily saline soils exhibited scattered spatial patterns in June, more concentrated spatial patterns were observed in July and October. The degree of soil salinization in October was stronger than other months. Most of the soils in October were categorized as moderate to heavily salinized soils with a low amount of non-salinized soils.

The cross-sections in different directions of the study field were selected to analyze the spatial characteristics of soil salts (Figure 4). For example, the A-A' and B-B' sections traversed from the northeast to the southwest of the study area, and the C-C' and D-D' sections traversed from the southwest to the northeast of the study area (Figure 2). In general, an increasing amount of salt accumulated in whole of the $0-100 \mathrm{~cm}$ soil profile from March to October (Figure 4). However, temporal differences were observed in the spatial distribution of soil salts. For example, in the northern part of the study area, the soil mainly changed from non-salinized soil to mild and moderately salinized from March to June. However, from June to July, the part of mildly and moderately salinized soil in the middle to the northern part of the study area became non-salinized. The area under moderately and heavily saline soil in the southern part of the experimental area increased during this time. However, from July to October, the area of mildly, moderately, and heavily saline soil increased significantly, and the area of non-saline soil decreased sharply. 


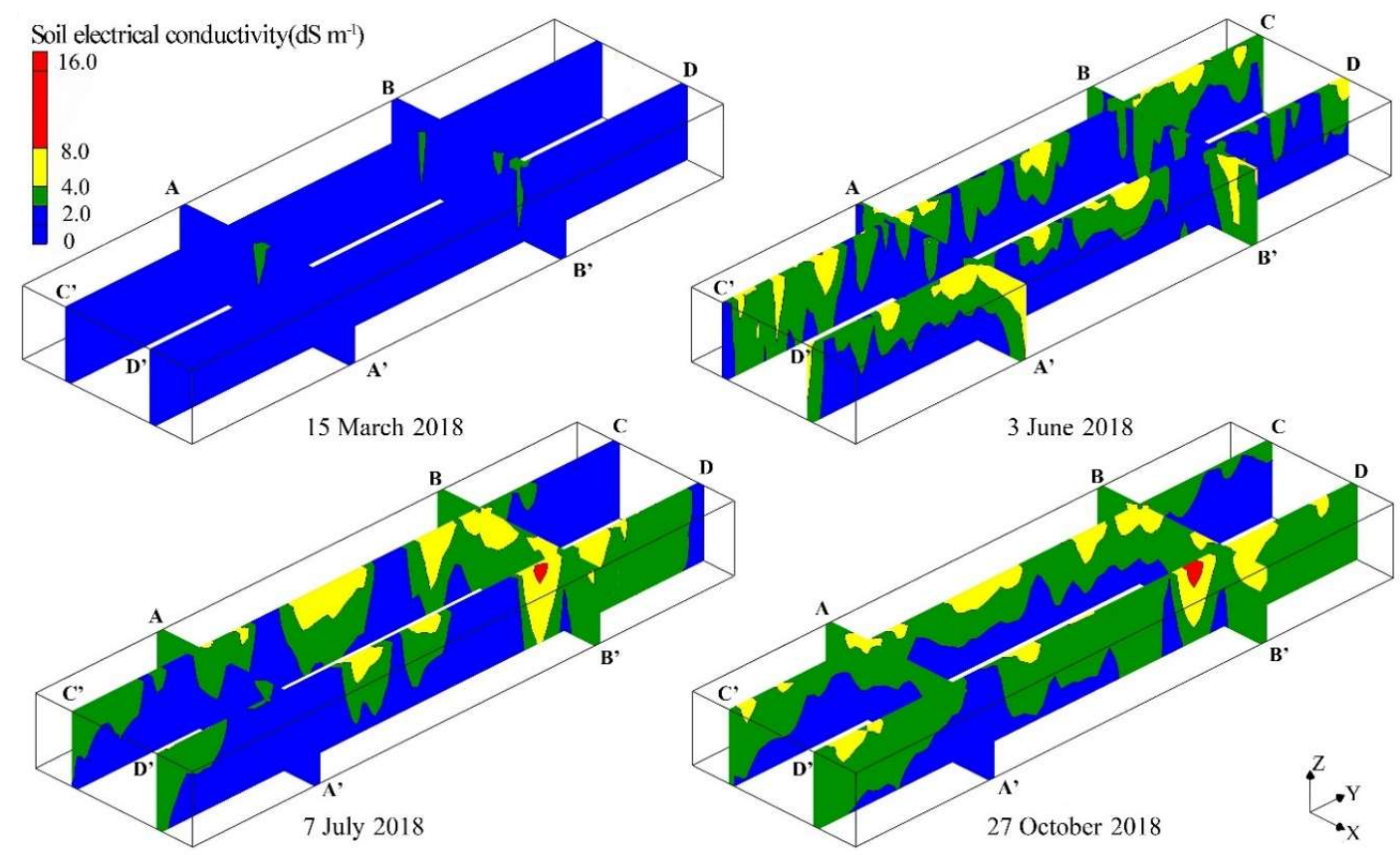

Figure 4. Cross sectional view of the distribution of soil salinity in three-dimensions at different periods.

\subsection{Soil Salinization Areas at Different Periods}

After 3D-IDW interpolation, each voxel had a soil conductivity value. In this paper, voxel was the basic unit, and the proportion to the total voxels occupying area by the five grades of salinized soil in each soil layer in different periods was calculated (Table 5). The area of non-salinized soil in the study area increased with depth at different periods, while the area of saline soil (mild, moderate, and severe) exhibited reverse pattern within the soil profile (Table 5). Salts exhibited a tendency to accumulate in the surface soil layers. This accumulation also differed with the amount of salts that are present in the soil profile. The salt accumulation pattern covering certain areas also varied with time. For example, the area of mildly salinized soil increased in soil layer of $0-20 \mathrm{~cm}$ to $20-40 \mathrm{~cm}$ while the area of mildly salinized soil decreased with increase in soil depth.

Table 5. Proportion of soil salinization grades in different periods of the test area.

\begin{tabular}{ccccccc}
\hline Date & Layer/cm & Non-Saline & Mildly Saline & Moderately Saline & Heavily Saline & Saline Soil \\
\hline & $0 \sim 20$ & 98.6 & 1.4 & 0 & 0 & 0 \\
15 March 2018 & $20 \sim 40$ & 99.0 & 1.0 & 0 & 0 & 0 \\
& $40 \sim 60$ & 99.3 & 0.7 & 0 & 0 & 0 \\
& $60 \sim 80$ & 99.5 & 0.5 & 0 & 0 & 0 \\
& $80 \sim 100$ & 99.6 & 0.4 & 0 & 1.1 & 0 \\
& $0 \sim 20$ & 30.9 & 41.0 & 27.0 & 0.2 & 0 \\
3 June 2018 & $20 \sim 40$ & 41.6 & 45.9 & 12.4 & 0.2 & 0 \\
& $40 \sim 60$ & 56.3 & 36.5 & 7.1 & 0.1 & 0 \\
& $60 \sim 80$ & 69.3 & 25.3 & 5.3 & 0.7 & 0 \\
& $80 \sim 100$ & 78.1 & 17.6 & 4.3 & 0 & 0 \\
7 July 2018 & $0 \sim 20$ & 36.0 & 39.1 & 24.2 & 0 & 0 \\
& $20 \sim 40$ & 42.8 & 42.8 & 14.2 & 0 & 0 \\
& $40 \sim 60$ & 53.8 & 40.3 & 5.9 & 0.2 & 0 \\
& $60 \sim 80$ & 65.1 & 32.1 & 2.8 & 0 & 0 \\
& $80 \sim 100$ & 75.5 & 23.0 & 1.6 & 0 & 0 \\
& $0 \sim 20$ & 7.8 & 62.3 & 29.7 & 0 & 0 \\
\hline
\end{tabular}


After the winter irrigation on 15 March, 99\% of the area became non-salinized soil with only a part as mildly saline soil. There is high probability of seasonal salinity in cotton fields in arid areas from the winter irrigation on 15 March to the cotton ball period on 3 June. Under the combined effects of evaporation and transpiration, deep groundwater carried soluble base ions with increased capillary action and enriched surface soil layers with salt. The proportion of non-saline soil gradually decreased at the surface layer. The proportion of salinized soil area (moderate, severe), exhibited an increasing-decreasing-increasing trend from the effect of drip irrigation with repeated rainfall in the surface soil $(0-20 \mathrm{~cm})$. The moderately and heavily saline soils were slightly reduced after leaching, while the areas of mildly saline soil in different soil layers were gradually increased.

The performance of 3D-IDW model was evaluated using cross-validation and the parameters are listed in Table 6. The ME ranged from -0.02 to 0.01 , the RMSE from 0.21 to $0.56 \mathrm{dS} \mathrm{m}^{-1}$, and $R^{2}$ from 0.76 to 0.77 . All these parameters indicated an acceptable performance of the model in predicting spatio-temporal changes of soil conductivity in three-dimensions.

Table 6. Independent cross-validated results of 3D-IDW interpolation at different dates.

\begin{tabular}{cccc}
\hline Date & $\boldsymbol{R}^{\mathbf{2}}$ & $\mathbf{R M S E}\left(\mathbf{d S} \mathbf{~ m}^{\mathbf{- 1}}\right)$ & $\mathbf{M E}$ \\
\hline 15 March 2018 & 0.77 & 0.21 & -0.02 \\
3 June 2018 & 0.76 & 0.27 & -0.02 \\
7 July 2020 & 0.76 & 0.40 & -0.03 \\
27 October 2018 & 0.77 & 0.56 & 0.01 \\
\hline
\end{tabular}

\section{Discussion}

\subsection{Model Performance}

Developing prediction relationship between field-measured soil electrical conductivity and the sensor-measured such as ground-based electromagnetic induction sensors or spectral index based remote sensing sensors is not new. For example, Rhoades and Crowin (1981) and Slavich (1990) successfully used multiple linear regression to correlate electromagnetic induction to ground measurement of soil profile $\mathrm{EC}_{\mathrm{a}}$ which provided a good reference for subsequent researches [37,38]. Liu et al. (2013) comprehensively used soil profile data and spectral index calculated from remote sensing imageries to analyze and evaluate spatial variability of three-dimensional salinity at regional scale [39]. This provided a way to quantify and improved the accuracy of the three-dimensional prediction of regional soil salinity. In this study, we used the electromagnetic induction-based sensor to measure $\mathrm{EC}_{\mathrm{a}}$ and use that as prior knowledge to optimize soil sampling. Then the apparent conductivity and the soil salt content at different depths were used to establish multivariate linear model. The predictive models show improved performance ( $R^{2}$ ranged from 0.824 to 0.994$)$ than previous studies $[25,40]$ and provided justification to use for further analysis.

Corwin and Lesch (2014) used covariance analysis to establish a regional-scale electromagnetic induction-salt calibration model. The model was used in other research areas and significantly reduced the number of soil samples required for modeling and greatly reduced the labor and economical cost [41]. Unlike the covariance modeling method, in this study we used the multivariate linear model for inversion of salinity from apparent conductivity at the farmland scale. The soil texture, bulk density, and water content in the study field are relatively uniform. Therefore, further study required to explore the extended application of our method at larger spatial scales. In this study, factors such as soil water content, $\mathrm{pH}$, soil texture were introduced as covariates in the multiple linear regression model. However, the accuracy of the model did not exhibit any significant improvement over the model with single covariate, the salt content. Thus, soil water content, $\mathrm{pH}$, and soil texture were not included in the final model. In addition, the inversion model of soil conductivity of different soil layers at four different periods was established. The accuracy of the local model and the global model were compared, and the local model with better performance was finally selected and applied in our study. 
However, as the local model development requires higher resources, future work should focus on developing global model with high performance to reduce the labor and economical cost when survey is conducted at large spatial scale. Similarly, different methods such as covariance modeling methods as well as machine learning need to be tested at large spatial scale, which already showed improved performance in soil management and precision agriculture.

Currently, obtaining three-dimensional discrete data of soil salinity through electromagnetic induction inversion models is one of the main ways to map 3D spatial variability of soil salinity $[25,40]$. An interpolation method can be used to estimate the target variables at non sampling sites $[25,42]$. Presently, the commonly used three-dimensional interpolation methods are mostly extended from the two-dimensional interpolation methods including IDW and Kriging. However, previous studies mainly focused on modeling geological bodies, and few studies concentrated on soil properties. Additionally, most of these spatial interpolation methods were developed with certain assumptions and have related limitations. For example, Kriging methods need to satisfy the second-order stationary hypothesis and the choice and fitness of semi-variance function has critical effects on the prediction accuracy [43-47]. In addition, Kriging methods would smooth detailed information which is usually what the end-users are concerned with especially in precision agriculture. IDW uses a simple reciprocal distance as weights to estimate the target variable at unmeasured sites. The IDW method includes a few parameters and is simple and easy to employ, which makes it one of the most widely used method [43,47-49]. Therefore, in this study we used 3D-IDW [50] to map spatio-temporal variation of soil salinity at three dimensions in the soil profile.

\subsection{Controlled Factors of Soil Secondary Salinization}

The spatio-temporal heterogeneity of soil salinization is caused by the interaction of natural and anthropogenic factors. Natural factors mainly include soil parent material, soil permeability, groundwater depth, topography and hydrogeology, rainfall, temperature, relative humidity, and wind speed. Anthropogenic or human factors mainly include farmland irrigation, drainage, farming styles, and planting systems [51-54]. In arid and semi-arid regions, when the amount of evaporation is greater than the rainfall and the depth of the local water table is less than $1.5 \mathrm{~m}$, the salt tends to accumulate on the soil surface. The experimental area is in extreme arid area of southern Xinjiang in Northwest of China, where the annual evaporation is 40 times of the annual rainfall [12]. The northern part of the study area is less than $0.5 \mathrm{~km}$ away from the Tarim River. The depth of the groundwater level in the test area varies with season and is affected by the flood season of the Tarim River. These anthropogenic and natural factors contribute to the three-dimensional distribution of soil salinity in different periods.

The main reason of non-saline soil in March is that the winter irrigation washes the soil salt to a depth of $>1 \mathrm{~m}$. Winter temperature also influences this as frozen soil layer prevents the upward movement and accumulation of soil salt. The main reason for the highest degree of salinization in June is the temperature. High temperature and strong evaporation draw water from salty and shallow groundwater through capillaries. In addition, the study area adopts drip irrigation under the film. The large area of exposed soil between the film is also affected by the temperature. These lead to the accumulation of salt at the soil surface and form salt crust. Moreover, the soil texture in the study area is mainly sandy loam, with poor water retention, resulting in the formation of secondary soil salinization. The degree of salt accumulation also depends on the leaching ratio; proportion of irrigation water or precipitation flowing outside the soil. As the leaching ratio decreases, soil salt gradually accumulates in the soil [5].

The flood season in the Tarim River basin is from July to September. The groundwater level in the study area is less than $1.5 \mathrm{~m}$ during this period. During this time, the study area only received one drip irrigation, and the maximum wetting depth was only $40 \mathrm{~cm}$. Affected by the uncovering of the film (cotton was harvested in October) and high temperature, the salts moved upward and formed secondary salinization in the surface soil. 
Soil salinity showed strong spatial and temporal heterogeneity. Within the root zone, the soil salinity generally is the result of the complex interaction of meteorology, topography, human factors, soil properties, soil genesis, and biological factors. The complex three-dimensional spatial distribution pattern of salt within the root system often has a coefficient of variation greater than $60 \%$ [55]. In arid areas, salt accumulations in the root zone can cause various problems for crops or plants development. Soil salinization affects the normal growth and development of crops and can also lead to reduction of crop yield. However, the harmful effects of soil salinity vary with crop types, climate, soil fertility, soil physical conditions, and soil moisture status [56]. Therefore, there is a greater uncertainty on the threshold of soil salinity that can pose negative effects on crop yield. Thus, the information on three-dimensional spatial distribution of soil salinity in different periods can essentially contribute to making more scientific field-management measures.

\subsection{Impacts of Precision Agriculture on Crop Yields and the Environment}

Traditional agricultural production inputs such as fertilizers, irrigation water, pesticides ignore the inherent spatial heterogeneity that exist between and within the fields. Uniform agricultural production inputs can lead to abuse of agricultural resources. In most of the cases, farmers would tend to increase the input of fertilizer and irrigation water to improve the crop yields. However, overuse of crop inputs can lead to decline in profitability and various environmental issues such as eutrophication [5]. The increase in global population is demanding more food, posing great pressure to our agricultural production systems. In this context, precision agriculture aims to make full use of the electronic information technology to monitor spatio-temporal variation of soil properties for site-specific management [57-60]. It can optimize production capacity and profitability of crops, maximize the use of limited agricultural inputs, and reduce the negative effects on the environment and humans [61]. Corwin and Plant (2005) introduced the application of electromagnetic induction technology $\mathrm{EC}_{\mathrm{a}}$ in precision agriculture [62]. At the beginning of the 21st century, the electromagnetic induction technology was mainly applied to crop management in specific locations $[63,64]$.

Currently, the precision agriculture mainly relies on real-time monitoring of soil conditions using information technology and GPS technology, and then analyzing and managing the spatio-temporal variability of soil and field crops. These information help make decision on precision application of crop inputs including water and fertilizer. It can improve the efficiency and reduce the losses of water and fertilizer. Precision irrigation can timely, accurately, and quantitatively match crops' water demand, reduce unnecessary runoff, leakage, and evaporation losses, and reduce soil nitrogen losses and groundwater salinity. Information on $3 \mathrm{D}$ variability of soil salinity at multiple times over the growing season can help develop decisions and adopt precision agriculture. Results obtained in this study could help us to get quantitative information about soil salt content and provide good foundation for understanding the relationship between water and salt structure as well as underlying processes of salt accumulation. Monitoring spatio-temporal variation of soil salinity at three dimensions in a timely and cheap manner is of great significance for maintaining the sustainable development of agricultural production mainly in the arid and semi-arid regions of the world and this study lays foundation of such an important topic.

\section{Conclusions}

Soil salinity is the most critical soil degradation issues around the world, particularly in the arid and semi-arid regions. Along with the natural factors, anthropogenic management of agricultural lands such as irrigation contributes to secondary soil salinity. Thus, monitoring and management of this salinity over the growing season are critical for sustainable management of these already vulnerable lands. In this study, we collected apparent electrical conductivity data (using electromagnetic induction sensing technology) and soil profile samples from a typical cotton field in arid areas for four times. We constructed inversion models of different soil layers in different periods and developed 3D-IDW interpolation model to quantify spatio-temporal variations of soil electrical conductivity. 
The main conclusions of this study can be summarized as:

(1) The inversion model showed very good performance for estimating the soil apparent conductivity with $R^{2}$ ranging between 0.824 and 0.994 .

(2) The soil electrical conductivity showed strong spatio-temporal variations. because of strong root activity and evaporation demand from environmental forcing, surface soil layer (0-20) exhibited moderate variability while other soil layers exhibited strong variability. After the cotton was harvested on 27 October, the variability in soil electrical conductivity became stable.

(3) After winter irrigation, the salt content was low, and the salts were uniformly distributed in the soil profile. After cotton sowing, salts were mainly accumulated in soil within the surface $0-40 \mathrm{~cm}$ depth. The main factors affecting the soil salt content and its distribution in different periods in the study area were irrigation, groundwater depth, degree of groundwater salinity, temperature, and the mulching plastic film.

(4) The 3D-IDW interpolation method showed good accuracy in predicting three-dimensional spatio-temporal variability of soil conductivity multiple times, and the $R^{2}$ varied between 0.76 and 0.77 .

This study provides new dimension in implementing precision irrigation practices in cotton fields in arid areas based on the three-dimensional variations of salts over the growing season.

Author Contributions: Conceptualization, B.H., A.B. and J.P.; methodology, X.L. and Q.J.; software, X.L.; validation, X.L., Q.J. and N.W.; formal analysis, J.P.; investigation, X.L., Q.J., W.L., N.W. and J.P.; resources, H.L., W.L. and J.P.; data curation, X.L.; writing-original draft preparation, X.L. and B.H.; writing-review and editing, X.L., B.H. and A.B.; visualization, X.L.; supervision, A.B. and J.P.; project administration, H.L. and J.P.; funding acquisition, H.L. and J.P. All authors have read and agreed to the published version of the manuscript.

Funding: This research was jointly funded by the Young and middle-aged Innovative Leaders Program of Xinjiang Production and Construction Corps (No. 2020CB032); the National Key Research and Development Program (No. 2018YFE0107000); the National Science Foundation of China (No. 42071068); and the Natural Science Foundation of Jiangxi Province (No. 20202BABL205025).

Conflicts of Interest: The authors have declared no competing interests. The founding sponsors had no role in designing the study; collection, analyses, or interpretation of data; writing of the manuscript, or the decision to publish the results.

\section{References}

1. Hossain, M.S. Present Scenario of Global Salt Affected Soils, its Management and Importance of Salinity Research. Int. Res. J. Biol. Sci. 2019, 1, 1-3.

2. Wicke, B.; Smeets, E.; Dornburg, V.; Vashev, B.; Gaiser, T.; Turkenburg, W.; Faaij, A. The global technical and economic potential of bioenergy from salt-affected soils. Energy Environ. Sci. 2011, 4, 2669-2681. [CrossRef]

3. Massoud, F.I. Salt Affected Soils at a Global Scale and Concepts for Control; FAO Land and Water Development Division, Technical Paper; Food and Agriculture Organization of the United Nations, FAO: Rome, Italy, 1981; p. 21.

4. Fitzpatrick, R.W.; Merry, R.; Cox, J. What are saline soils and what happens when they are drained? J. Austral. Assoc. Nat. Res. Manag. 2000, 6, 26-30.

5. Corwin, D.L.; Scudiero, E. Review of soil salinity assessment for agriculture across multiple scales using proximal and/or remote sensors. Adv. Agron. 2019, 158, 1-130.

6. Chang, C.; Laird, D.A. Near-infrared reflectance spectroscopic analysis of soil C and N. Soil Sci. 2002, 167, 110-116. [CrossRef]

7. Shepherd, K.D.; Walsh, M.G. Development of reflectance spectral libraries for characterization of soil properties. Soil Sci. Soc. Am. J. 2002, 66, 988-998. [CrossRef]

8. Rhoades, J.D.; Ingvalson, R.D. Determining salinity in field soils with soil resistance measurements. Soil Sci. Soc. Am. J. 1971, 35, 54-60. [CrossRef]

9. Rhoades, J.D.; van Schilfgaarde, J. An Electrical Conductivity Probe for Determining Soil Salinity. Soil Sci. Soc. Am. J. 1976, 40, 647-651. [CrossRef] 
10. Rhoades, J.D.; Lesch, S.M.; LeMert, R.D.; Alves, W.J. Assessing irrigation/drainage/salinity management using spatially referenced salinity measurements. Agric. Water Manag. 1997, 35, 147-165. [CrossRef]

11. Yao, R.; Yang, J.; Liu, G. Calibration of soil electromagnetic conductivity in inverted salinity profiles with an integration method. Pedosphere 2007, 17, 246-256. [CrossRef]

12. Peng, J.; Biswas, A.; Jiang, Q.; Zhao, R.; Hu, J.; Hu, B.; Shi, Z. Estimating soil salinity from remote sensing and terrain data in southern Xinjiang Province, China. Geoderma 2019, 337, 1309-1319. [CrossRef]

13. Gorji, T.; Yildirim, A.; Hamzehpour, N.; Tanik, A.; Sertel, E. Soil salinity analysis of Urmia Lake Basin using Landsat-8 OLI and Sentinel-2A based spectral indices and electrical conductivity measurements. Ecol. Indic. 2020, 112, 106173. [CrossRef]

14. Lesch, S.M. Sensor-directed response surface sampling designs for characterizing spatial variation in soil properties. Comput. Electron. Agric. 2005, 46, 153-179. [CrossRef]

15. Guo, Y.; Zhou, Y.; Zhou, L.; Liu, T.; Wang, L.; Cheng, Y.; Zheng, G. Using proximal sensor data for soil salinity management and mapping. J. Integr. Agric. 2019, 18, 340-349. [CrossRef]

16. Jiang, Q.; Peng, J.; Biswas, A.; Hu, J.; Zhao, R.; He, K.; Shi, Z. Characterising dryland salinity in three dimensions. Sci. Total Environ. 2019, 682, 190-199. [CrossRef]

17. Marchant, B.P.; Saby, N.P.A.; Jolivet, C.C.; Arrouays, D.; Lark, R.M. Spatial prediction of soil properties with copulas. Geoderma 2011, 162, 327-334. [CrossRef]

18. Saby, N.P.A.; Marchant, B.P.; Lark, R.M.; Jolivet, C.C.; Arrouays, D. Robust geostatistical prediction of trace elements across France. Geoderma 2011, 162, 303-311. [CrossRef]

19. Lacarce, E.; Saby, N.P.; Martin, M.P.; Marchant, B.P.; Boulonne, L.; Meersmans, J.; Arrouays, D. Mapping soil $\mathrm{Pb}$ stocks and availability in mainland France combining regression trees with robust geostatistics. Geoderma 2012, 170, 359-368. [CrossRef]

20. Orton, T.G.; Saby, N.P.A.; Arrouays, D.; Jolivet, C.C.; Villanneau, E.J.; Marchant, B.P.; Briand, O. Spatial distribution of Lindane concentration in topsoil across France. Sci. Total Environ. 2013, 443, 338-350. [CrossRef]

21. Xia, F.; Hu, B.; Shao, S.; Xu, D.; Zhou, Y.; Zhou, Y.; Shi, Z. Improvement of Spatial Modeling of Cr, Pb, Cd, As and Ni in Soil Based on Portable X-ray Fluorescence (PXRF) and Geostatistics: A Case Study in East China. Int. J. Environ. Res. Public Health 2019, 16, 2694. [CrossRef]

22. Boente, C.; Martín-Méndez, I.; Bellan, A.; Gallego, J.R. A novel and synergistic geostatistical approach to identify sources and cores of Potentially Toxic Elements in soils: An application in the region of Cantabria (Northern Spain). J. Geochem. Explor. 2020, 208, 106397. [CrossRef]

23. Liu, W.; Xu, X.; Lu, F.; Cao, J.; Li, P.; Fu, T.; Chen, G.; Su, Q. Three-dimensional mapping of soil salinity in the southern coastal area of Laizhou Bay, China. Land Degrad. Dev. 2018, 29, 3772-3782. [CrossRef]

24. Li, H.Y.; Shi, Z.; Webster, R.; Triantafilis, J. Mapping the three-dimensional variation of soil salinity in a rice-paddy soil. Geoderma 2013, 195, 31-41. [CrossRef]

25. Liu, G.; Li, J.; Zhang, X.; Wang, X.; Lv, Z.; Yang, J.; Shao, H.; Yu, S. GIS-mapping spatial distribution of soil salinity for Eco-restoring the Yellow River Delta in combination with Electromagnetic Induction. Ecol. Eng. 2016, 94, 306-314. [CrossRef]

26. Heil, K.; Schmidhalter, U. Comparison of the EM38 and EM38-MK2 electromagnetic induction-based sensors for spatial soil analysis at field scale. Comput. Electron. Agric. 2015, 110, 267-280. [CrossRef]

27. Sudduth, K.A.; Drummond, S.T.; Kitchen, N.R. Accuracy issues in electromagnetic induction sensing of soil electrical conductivity for precision agriculture. Comput. Electron. Agric. 2001, 31, 239-264. [CrossRef]

28. Amakor, X.N.; Jacobson, A.R.; Cardon, G.E.; Hawks, A. A comparison of salinity measurement methods based on soil saturated pastes. Geoderma 2014, 219, 32-39. [CrossRef]

29. Liu, X.; Peng, J.; Feng, C.; Wu, J.; Luo, D.; Qi, W. Research on the inversion model for soil conductivity of cotton field using EM38-MK2 data in southern Xinjiang. Acta Pedol. Sin. 2020, 57, 646-655.

30. Richards, L.A. Diagnosis and Improvement of Saline and Alkali Soils; United States Salinity Laboratory Staff. Agriculture Handbook No. 60; USDA and IBH Pub. Coy Ltd.: Washington, DC, USA, 1954; pp. 98-99.

31. Van Meirvenne, M.; Maes, K.; Hofman, G. Three-dimensional variability of soil nitrate-nitrogen in an agricultural field. Biol. Fertil. Soils 2003, 37, 147-153. [CrossRef]

32. Saeys, W.; Mouazen, A.M.; Ramon, H. Potential for onsite and online analysis of pig manure using visible and near infrared reflectance spectroscopy. Biosyst. Eng. 2005, 91, 393-402. [CrossRef] 
33. Franke, R.; Nielson, G. Smooth interpolation of large sets of scattered data. Int. J. Numer. Methods Eng. 1980, 15, 1691-1704. [CrossRef]

34. Robinson, T.P.; Metternicht, G.M. Testing the performance of spatial interpolation techniques for mapping soil properties. Comput. Electeron. Agric. 2006, 50, 97-108. [CrossRef]

35. Yun, A.; Ju, Z.; Hu, K.; Liang, H. Three-dimensional Spatial Interpolation of Soil Salinity Based on Inverse Distance Weighting Method. Trans. Chin. Soc. Agric. Mach. 2015, 46, 148-172.

36. Shi, Z.; Li, Y.; Wang, R.C.; Makeschine, F. Assessment of temporal and spatial variability of soil salinity in a coastal saline field. Environ. Geol. 2005, 48, 171-178. [CrossRef]

37. Rhoades, J.D.; Corwin, D.L. Determining soil electrical conductivity-Depth relations using an inductive electromagnetic soil conductivity meter. Soil Sci. Soc. Am. J. 1981, 45, 255-260. [CrossRef]

38. Slavich, P.G. Determining ECa-depth profiles from electromagnetic induction measurements. Aust. J. Soil. Res. 1990, 28, 443-452. [CrossRef]

39. Liu, G.M.; Wu, Y.K.; Yang, J.S.; Yu, S.P. Study on Three-dimension spatial variability of regional soil salinity based on spectral indices. Spectrosc. Spectr. Anal. 2013, 33, 2758-2761.

40. Wu, Y.K.; Liu, G.M.; Su, L.T. Response of three-dimensional spatial variability of soil salinity to change of season of Xinjiang based on electromagnetic induction. Trans. Chin. Soc. Agric. Eng. (Trans. CSAE) 2017, 33, 173-178.

41. Corwin, D.L.; Lesch, S.M. A simplified regional-scale electromagnetic induction-Salinity calibration model using ANOCOVA modeling techniques. Geoderma 2014, 230, 288-295. [CrossRef]

42. Simonka, V.; Nawratil, G.; Hossinger, A.; Weinbub, J.; Selberherr, S. Anisotropic interpolation method of silicon carbide oxidation growth rates for three-dimensional simulation. Solid State Electron. 2017, 128, 135-140. [CrossRef]

43. Webster, R.; Oliver, M.A. Geostatistics for Environmental Scientists; John Wiley \& Sons Inc.: Hoboken, NJ, USA, 2007.

44. Hu, B.; Shao, S.; Fu, Z.; Li, Y.; Ni, H.; Chen, S.; Zhou, Y.; Jin, B.; Shi, Z. Identifying heavy metal pollution hot spots in soil-rice systems: A case study in South of Yangtze River Delta, China. Sci. Total Environ. 2019, 658, 614-625. [CrossRef]

45. Fei, X.; Lou, Z.; Xiao, R.; Ren, Z.; Lv, X. Contamination assessment and source apportionment of heavy metals in agricultural soil through the synthesis of PMF and GeogDetector models. Sci. Total Environ. 2020, 747, 141293. [CrossRef]

46. Hu, B.; Zhou, Y.; Jiang, Y.; Ji, W.; Fu, Z.; Shao, S.; Li, S.; Huang, M.X.; Zhou, L.Q.; Shi, Z. Spatio-temporal variation and source changes of potentially toxic elements in soil on a typical plain of the Yangtze River Delta, China (2002-2012). J. Environ. Manag. 2020, 271, 110943. [CrossRef]

47. Hu, B.; Shao, S.; Fu, T.; Fu, Z.; Zhou, Y.; Li, Y.; Qi, L.; Chen, S.C.; Shi, Z. Composite assessment of human health risk from potentially toxic elements through multiple exposure routes: A case study in farmland in an important industrial city in East China. J. Geochem. Explor. 2020, 210, 106443. [CrossRef]

48. Jia, X.; Fu, T.; Hu, B.; Shi, Z.; Zhou, L.; Zhu, Y. Identification of the potential risk areas for soil heavy metal pollution based on the source-sink theory. J. Hazard. Mater. 2020, 393, 122424. [CrossRef]

49. Qi, Z.; Gao, X.; Qi, Y.; Li, J. Spatial distribution of heavy metal contamination in mollisol dairy farm. Environ. Pollut. 2020, 263, 114621. [CrossRef]

50. He, Q.; Zhang, Z.; Yi, C. 3D fluorescence spectral data interpolation by using IDW. Spectrochim. Acta Part A Mol. Biomol. Spectrosc. 2008, 71, 743-745. [CrossRef]

51. Rhoades, J.D.; Chanduvi, F.; Lesch, S.M. Soil Salinity Assessment: Methods and Interpretation of Electrical Conductivity Measurements. FAO Irrigation and Drainage Paper (FAO). 1999. Available online: https:/landviser.net/content/soil-salinity-assessment-methods-and-interpretation-electric al-conductivity-measurements (accessed on 4 December 2020).

52. Samake, O.; Smaling, E.M.; Kropff, M.J.; Stomph, T.J.; Kodio, A. Effects of cultivation practices on spatial variation of soil fertility and millet yields in the Sahel of Mali. Agric. Ecosyst. Environ. 2005, 109, 335-345. [CrossRef]

53. Yemefack, M.; Rossiter, D.G.; Njomgang, R. Multi-scale characterization of soil variability within an agricultural landscape mosaic system in southern Cameroon. Geoderma 2005, 125, 117-143. [CrossRef] 
54. Wei, J.B.; Xiao, D.N.; Zeng, H.; Fu, Y. Spatial variability of soil properties in relation to land use and topography in a typical small watershed of the black soil region, northeastern China. Environ. Geol. 2008, 53, 1663-1672. [CrossRef]

55. Corwin, D.L.; Kaffka, S.R.; Hopmans, J.W.; Mori, Y.; Van Groenigen, J.W.; Van Kessel, C.; Oster, J.D. Assessment and field-scale mapping of soil quality properties of a saline-sodic soil. Geoderma 2003, 114, 231-259. [CrossRef]

56. Grieve, C.M.; Grattan, S.R.; Maas, E.V. Plant salt tolerance. Agric. Salin. Assess. Manag. 2012, 2, $405-459$.

57. Amaral, J.P.; Oliveira, L.M.L.; Rodrigues, J.J.P.C.; Han, G.; Shu, L. Policy and network-based intrusion detection system for IPv6-enabled wireless sensor networks. In Proceedings of the 50th IEEE International Conference on Communications (ICC 2014), Sydney, Australia, 10-14 June 2014; pp. 1796-1801.

58. Behzadan, A.; Anpalagan, A.; Woungang, I.; Ma, B.; Chao, H.C. An energy efficient utility-based distributed data routing scheme for heterogeneous sensor networks. Wirel. Commun. Mob. Comput. 2015, 15, 2020-2037. [CrossRef]

59. Dhurandher, S.K.; Sharma, D.K.; Woungang, I.; Saini, A. Efficient routing based on past information to predict the future location for message passing in infrastructure-less opportunistic networks. J. Supercomput. 2015, 71, 1694-1711. [CrossRef]

60. Chen, N.; Zhang, X.; Wang, C. Integrated open geospatial web service enabled cyber-physical information infrastructure for precision agriculture monitoring. Comput. Electron. Agric. 2015, 111, 78-91. [CrossRef]

61. Van Schilfgaarde, J. Is precision agriculture sustainable? Am. J. Altern. Agric. 1999, 14, 43-46. [CrossRef]

62. Corwin, D.L.; Plant, R.E. Applications of apparent soil electrical conductivity in precision agriculture. Comput. Electron. Agric. 2005, 46, 1-10. [CrossRef]

63. Corwin, D.L.; Lesch, S.M. Apparent soil electrical conductivity measurements in agriculture. Comput. Electron. Agric. 2005, 46, 11-43. [CrossRef]

64. Corwin, D.L. Past, present, and future trends of soil electrical conductivity measurement using geophysical methods. In Handbook of Agricultural Geophysics; Allred, B.J., Daniels, J.J., Ehsani, M.R., Eds.; CRC Press: Boca Raton, FL, USA, 2008; pp. 17-44.

Publisher's Note: MDPI stays neutral with regard to jurisdictional claims in published maps and institutional affiliations.

(C) 2020 by the authors. Licensee MDPI, Basel, Switzerland. This article is an open access article distributed under the terms and conditions of the Creative Commons Attribution (CC BY) license (http://creativecommons.org/licenses/by/4.0/). 